術前に診断された食道と胆囊の同時性重複癌の 1 例

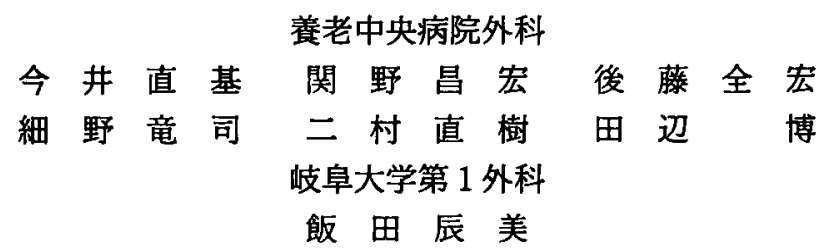

症例は77葴・男性であり, 肺結核・気管支喘息にて近医で治療を受けていた．平成 4 年 5 月右季肋部痛に気づき, 超音波検査にて胆石と胆毫腫瘍を指摘され当院を紹介され た. 諸検查にて食道と胆衰の同時性重複癌と診断した. 高龄者であり肺合併症を考慮し, 非開胸式食道抜去術，頸部食道一胃管吻合術と, 拡大胆售摘出術 $+R_{2}$ を施行した. 食道 は壁深達度 sm の高分化型扁平上皮癌であった. 胆葍は壁樑達度 ss の腺扁平上皮癌であ り, $\mathrm{n}_{2}(+)$, stage III であった. 術後, 縫合不全と呼吸不全をきたしたが軽快し, 第107 病日退院した。

食道と胆衰の同時性重複癌は稀であり，本邦報告例は本症例を含めて 6 例のみで，う ち 2 例は同時性 3 重複癌であった。これらのなかで術前診断されたものは本症例のみで あった. 食道と他蔵器重複癌は, 食道癌治療の困難性に加え, 他葴器癌が重複するため 予後は不良とされている.そのため治療方針の決定は慎重に行う必要があると思われた.

索引用語：食道癌, 胆萎癌, 同時性重複癌

\section{はじめに}

近年, 癌に対する診断技術の進歩と治療成績の向上 により, 重複癌の報告は増加しつつある.しかし食道 の同時性重複癌症(列の予後は不良”とされており, 治 療方法の選択は慎重に行う必要がある.

今回われわれは, 胆蔁癌の精查中に食道癌が発見さ れた同時性重複癌の 1 例を経験したので, 文献的考察 を加えて報告する。

$$
\text { 症例 }
$$

患者：77歳，男性.

主訴: 右季肋部痛.

家族歴：特記すべきことなし．

既往歴：76歳時より肺結核にて治療中.

現病歴: 平成 4 年 5 月より右季肋部痛が出現し, 近 医にて胆石と胆蕒腫瘍を指摘され，当院を紹介された。

現症：左胸部の呼吸音が減弱していた。腹部は平 坦・軟で, 右季肋部に軽度の圧痛を認めた。

入院時検查成績：白血球数 $4,800 / \mathrm{mm}^{3}, \mathrm{CRP}(+)$

1993年10月18日受付 1994年 3月10日採用
であった. 肝機能では ALP 304IU $/ l$ と軽度上昇し,そ の分画では ALP2が71\%を占めていた，腫場マーカー では CEA 9.7ng/ml, CA19-9 120U/ml, SCC 5.1ng/ $\mathrm{ml}$ といずれも上昇していた。肺機能検査では\%肺活量 $41.6 \% ， 1$ 秒率 $70.1 \%$ と拘束性障害を認めたが, 血液 ガス検査では正常範囲内であった。

胸腹部単純 $\mathrm{X}$ 線像：胸部写真では左肺上葉は新痕 収縮し，右肺は代償性に過膨張していた。腹部写真で は X 線陽性の胆石を認めた（図 1)。

腹部超音波検查：胆衰内には数個の胆石と, 底部前 壁には内腔に突出する $4 \times 3 \times 3 \mathrm{~cm}$ の腫瘾を認めた（図 2 ).

胸腹部 Computed tomography（以下 CT）検査： 腹部 CT では胆宾内に数個の胆石と, 肝臟とほほ isodensity の腫留を認めた（図了）。胸部 CT では明らか なリンパ節転移を認めなかった，同時に施行した胸腹 部 Magnetic resonance imaging でもほほ同様の所見 を得た。

内視鏡的逆行性胆道造影検査：胆表底部前壁に陰影 欠損を認めた. 


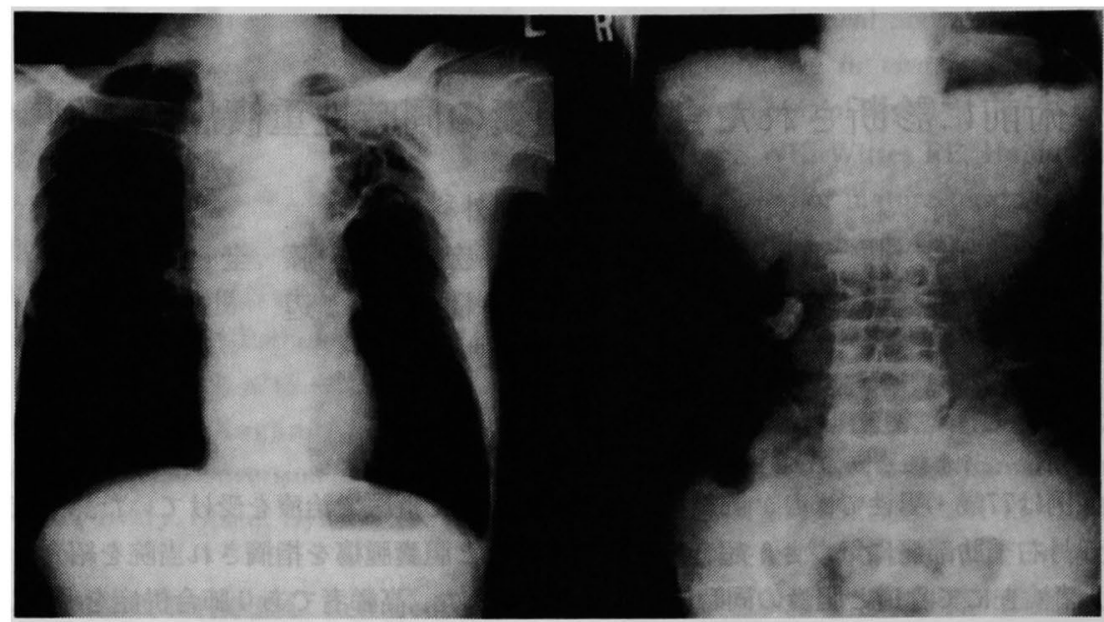

図 1 单純 X 線写真：胸部 (左側)ては左肺上葉は疫痕収縮し右肺は代侻性に過膨脹 していた。腹部（右側）では X 線陽性の胆石を認めた。

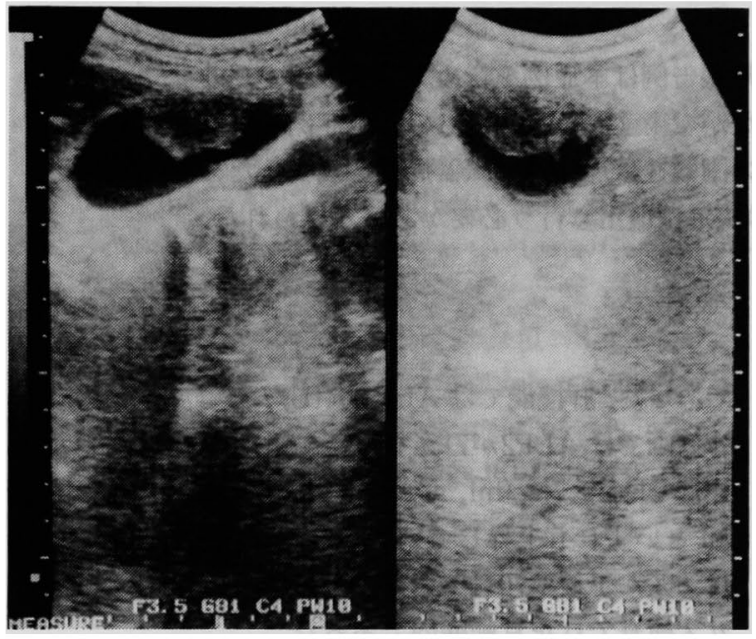

图 2 腹部超音波検査 : 胆裹内には数個の胆石と, 底 部前壁には内腔に突出する $4 \times 3 \times 3 \mathrm{~cm}$ の腫瘤を認 めた.

腹部血管造影検査：動脈相での encasement 像, 門 脈相での腫場塞栓像や腫瘍内 pooling 像は認めなかっ た.

上部消化管造影検查：胸部中部食道後壁左よりに， 腫瘤型の陰影欠損を認めた（図4).

食道内視鏡検查：門歯よりに28～30cmに，境界明 瞙・白色・易出血性の隆起型病変を認め（図 5 ), 生検 にて Group V と診断された。

以上の所見により食道と胆重の同時性重複癌と診断 し手術を施行した。

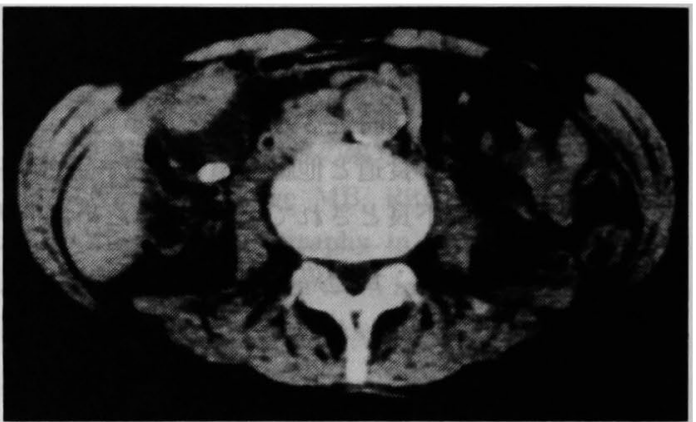

図 3 腹部 CT 検查：胆喜内に数個の胆石と, 肝臟と ほほ iso-density の腫痛を認めた。

手術所見：開腹すると腹膜播腫・肝転移は認めな かった，胆荛壁は軽度肥大し，大豆大の胆石を数個触 知した。胆亳底部前壁には漿膜浸潤が疑われる胡桃大 の硬い腫瘤を触知した．肝十二指腸間膜内リンパ節お よび総肝動脈幹リンパ節には転移が疑われた。肉眼的 進行度は， $\mathrm{N}_{2} \mathrm{~S}_{1} \mathrm{P}_{0} \mathrm{H}_{0} \operatorname{Hinf}_{0}$ Binf $_{0}$ Stage III と診断 し， $R_{2}$ 郭清を伴う拡大胆蓑摘出術を施行した。食道癌 に対しては非開胸食道抜去術を施行し，後䋛隔経路に よる頸部食道一胃管吻合にて再建し，空腸瘦を造設し た。

摘出標本所見：胸部中部食道後壁には $2.3 \times 1.2 \mathrm{~cm}$ の比較的境界明瞭な隆起性病変を認めた，胆业底部前 壁には $4 \times 3 \times 3 \mathrm{~cm}$ の乳頭浸潤型の腫留を認めた（図 $6)$.

病理組織学的所見：食道病変は高分化型扁平上皮 


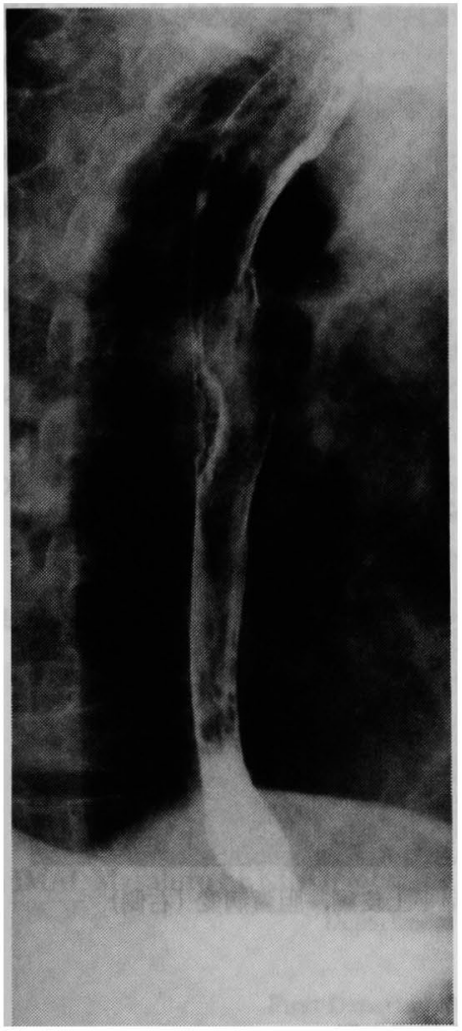

図 4 食道造影検査: 胸部中部食道後壁左寄りに, 腫 瘤型の陰影欠損を認めた。

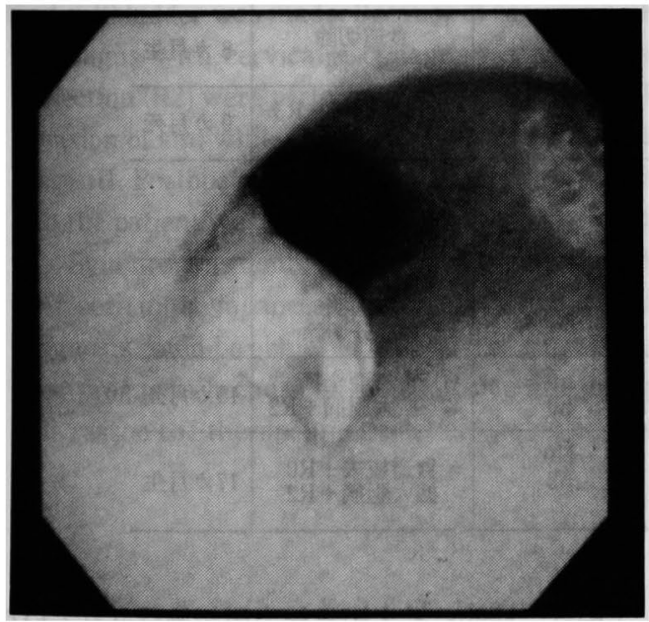

图 5 食道内視鏡検查: 門歯より $28 \sim 30 \mathrm{~cm}$ に, 境界 明瞕・白色・易出血性の隆起性病変を認めた。

癌, $\mathrm{sm}, \mathrm{ly}_{0}, \mathrm{v}_{0}$ であった. 胆咅病変はほとんどが扁平 上皮癌様であるが，一部に腺癌様病変が併存する腺扁

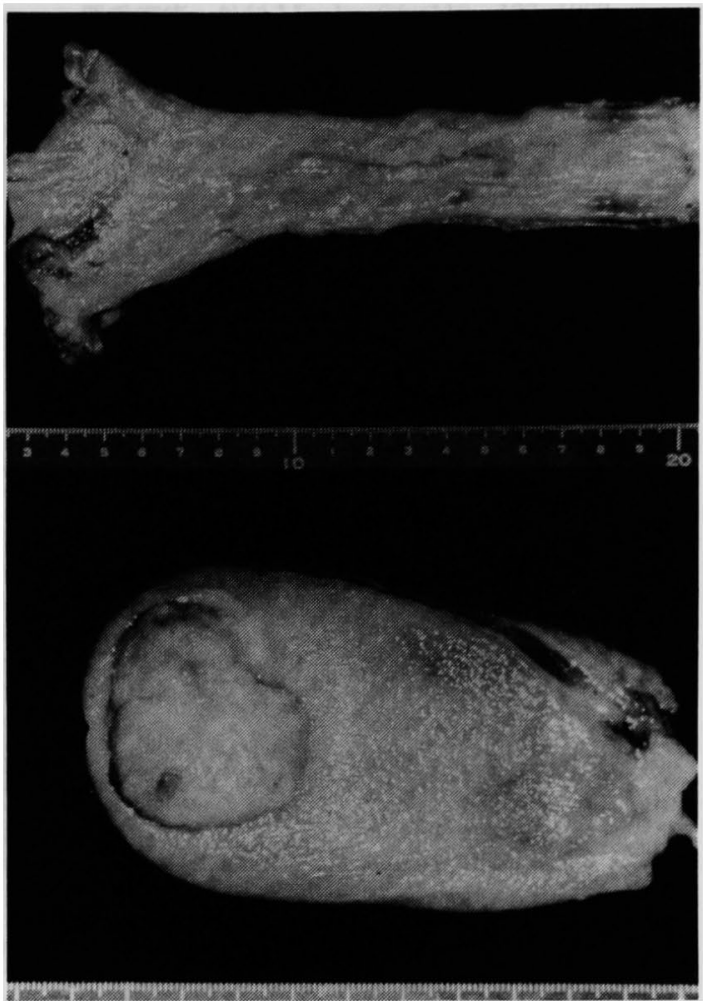

图 6 摘出標本：食道 (上)には $2.3 \times 1.2 \mathrm{~cm}$, 胆莗 (下) には $4 \times 3 \times 3 \mathrm{~cm}$ の乳頭浸潤型の腫瘍を認めた。

平上皮癌，ss， $\mathrm{ly}_{0} ， \mathrm{v}_{0}$ であった（図 7)，12c・12b・12 $\mathrm{p} \cdot 8 \mathrm{a}$ のリンパ節には, 高分化型腺癌様の転移を認め た. CEA 染色およびCA19-9染色では, いずれの病変 も染色されなかった。

術後経過：第 5 病日より縫合不全, 第13病日より呼 吸不全をきたしたため人工呼吸器を装着し, 高力口 リー輸液と経腸栄養を併用した。第54病日に人工呼吸 器から離脱し, 第107病日に退院した。術後 1 年 5 力月 経過した現在, 再発の徴候は見られず健在である.

$$
\text { 考察 }
$$

近年, 癌に対する診断技術の進歩や遠隔成績の向上 により重複癌の報告が增加している. 阿保ら”は，食道 と他臟器重複癌は同時性が2.1\%, 異時性が1.5\%で あったとしており, 重複臟器は胃が76.5\%と最も多く,

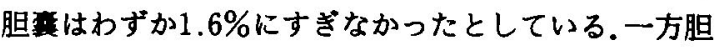
烡と他臟器重複癌について近藤ら゙2は, 40例の報告の うち重複葴器は胃が62.5\%を占めたとしている．われ われが調べ得た限りでは，欧米における食道と胆䢂の 同時性重複癌の報告例はなく, 本邦においても本症例 

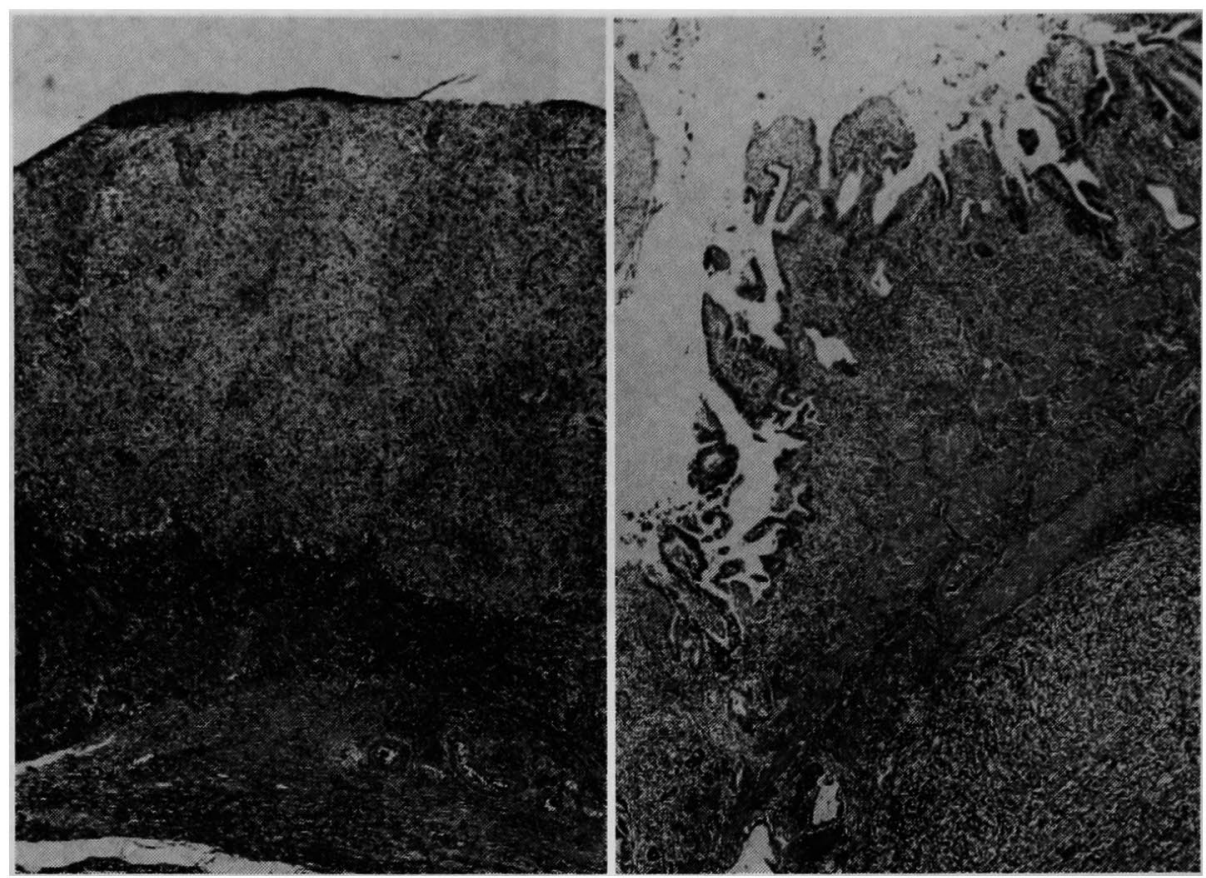

図 7 病理組織学的検查：食道病変 (左㑡) は高分化型扁平上皮虞, 胆妾病変 (右側) は腺扁平上皮癌であった（H.E. stain $\times 40 ）$.

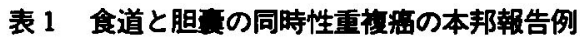

\begin{tabular}{|c|c|c|c|c|c|c|c|c|c|}
\hline No. & 年 & 報告者 & 年龄 & 性 & 術前診断 & 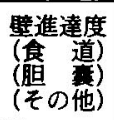 & $\begin{array}{l}\text { リンパ節 } \\
\text { (食 道) } \\
\text { (盟) } \\
\text { (その他) }\end{array}$ & 手術術式 & 予 後 \\
\hline 1 & 1978 & 島 $5^{31}$ & 59 & 男 & 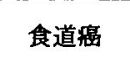 & & & $\begin{array}{l}\text { 食道切除 } \\
\text { 腿 摘 }\end{array}$ & 8 力月生 \\
\hline 2 & 1982 & 川崎ら & 48 & 男 & 食道湯 & sm & $\begin{array}{l}\text { n2 } \\
\text { No }\end{array}$ & $\begin{array}{c}\text { 食道粟全摘+ } \\
\text { 䐱 }\end{array}$ & 9 力月死 \\
\hline 3 & 1985 & 近藤ら & 60 & 男 & 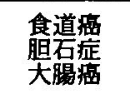 & $\begin{array}{l}\mathrm{m} \\
\mathrm{m} \\
\mathrm{ss}\end{array}$ & $\begin{array}{l}\text { no } \\
\text { N0 }\end{array}$ & $\begin{array}{c}\text { 食道要全摘 } \\
\text { 装 } \\
\mathrm{S} \text { 状結晹切除 }\end{array}$ & \\
\hline 4 & 1985 & 柿坂 & 70 & 男 & $\begin{array}{l}\text { 食道㾇 } \\
\text { 照石症 } \\
\text { 癌 }\end{array}$ & $\begin{array}{c}\mathrm{mp} \\
\mathrm{sS} \\
\mathrm{sm}\end{array}$ & $\begin{array}{l}\text { No } \\
\text { No }\end{array}$ & $\begin{array}{l}\text { 食道要全摘 } \\
\text { 摘 } \\
\text { 胃部分切除 }\end{array}$ & 2 年生 \\
\hline 5 & 1992 & 渡部ら & 77 & 男 & (1) 食道漂 & $\mathrm{mp}$ & $\begin{array}{l}\text { n0 } \\
\text { n0 }\end{array}$ & 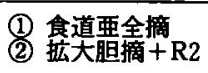 & 19力月死 \\
\hline 6 & 1993 & 自験例 & 77 & 男 & 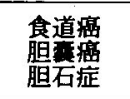 & $\begin{array}{l}\mathrm{sm} \\
\mathrm{ss}\end{array}$ & $\begin{array}{l}\text { N0 } \\
\text { n2 }\end{array}$ & 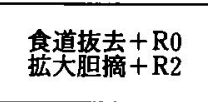 & 17力月生 \\
\hline
\end{tabular}

を含めて 6 例2) -6)(表 1 )のみであった。これらはすべ て男性であり，うち 2 例は大腸癌または胃癌を伴う 3 重複癌であった。全例食道癌の術前診断はされていた が, 胆董癌の術前診断がなされたものは本症例のみで あった。他の 5 例はいずれも術中または術後に胆暴癌 と診断され，うち 4 例は同時に胆毫摘出のみが施行さ
れ，1 例は二期的に拉大胆顀摘出術が施行されていた。 食道癌と他臟器重複癌の場合, 食道癌治療の困難性 に加えて, 他臟器癌が重複するため予後不良とされて いる. 特に同時性食道重複癌の予後は不良であり，阿 保ら"は 1 年以内に $72 \%$ 多亡したと報告している。 重複癌の治療は術前合併症を考慮した上に 2 病変に 
対する過不足ない治療が必要でる。本症例の場合, 77歳と高齢であり，左肺上葉疫痕収縮によると思われ る肺機能の低下も認めた。このため右開胸による食道 要全摘は困難と考え，姑息的ではあるが侵紊の少ない 非開胸食道抜去術を選択した。

\section{結語}

術前診断された食道と胆售の同時性重複庫の 1 例を 報告した。この様な食道と他臟器同時性重複癌に対す る治療法の選択は慎重に行う必要があると考えられ た.

本論文の要旨は第 242 回東海外科学会例会において報告 した.

1) 阿保七三郎, 三浦秀男, 工藤 保他：食道蹈と他臓
器重複癌。外科 Mook $24: 119-127,1982$

2）近藤高志, 石井康袸, 小林 滋他：同時性三重複癌 （食道，胆蓄，大腸）の 1 例。癌の臨 $31 ： 1849$ $-1853,1985$

3）島 伸吾, 掛川暉夫, 別所 隆他：食道と他䑏器重 複癌14例の検討. 外科診療 $20: 195-198,1978$

4）川崎雄三, 末永䅧邦, 吉中平次他：食道と胆言の同 時性重複癌の 1 例。臨外 $37: 1133-1138,1982$

5）柿坂明俊，紀野修一，草野满夫他：食道, 胃, 胆毫 三重複癌の 1 例. 北海道外科誌 $30: 182-186$, 1985

6）渡辺誠一郎, 古川正人, 中田俊則他：食道アカラシ アに合併した食道·胆塞重複癌の 1 例. 日臨外医会 誌 $53: 2971-2975,1992$

\title{
A CASE OF SYNCHRONOUS DOUBLE CANCER OF THE ESOPHAGUS AND GALLBLADDER SUCCESSFULLY DIAGNOSED PREOPERATIVELY
}

\author{
Naoki IMAI, Masahiro SEKINO, Masahiro GOTO, Ryuji HOSONO, Naoki FUTAMURA and Hiroshi TANABE \\ Department of Surgery, General Yoro Central Hospital \\ Tatsumi IIDA \\ First Department of Surgery, Gifu University School of Medicine
}

A 77-year-old man, who had been treated for pulmonary tuberculosis and bronchial asthma at a nearby hospital, noticed right hypochondralgia in May 1992. Ultrasonography indicated gallstone and a gallbladder tumor and he was referred to the hospital. With examinations a diagnosis of synchronous double cancer of the esophagus and gallbladder was made. Because of his advanced age and pulmonary complications, closed heart evultion of the esophagus with cervical esophagus-gastric tube anastomosis and extended cholecystectomy with lymph node dissection (R2) were performed. The esophageal tumor was well differentiated squamous cell carcinoma with wall invasion of sm; while the cystic tumor was adenosquamous cell carcinoma with wall invasion of ss and $n 2(+)$ in stage III. Postoperatively suture failure and respiratory failure developed, but which were successfully managed and the patient was discharged from the hospital on 170th hospital day.

Synchronous double cancer of the esophagus and gallbladder is rare, and only 6 cases including this case have been seen in the Japanese literature, which included 2 cases of synchronous triple cancer. Among them preoperative diagnosis could be achieved only in this case. It is said that double cancer of the esophagus and other organ has a poor prognosis because of the difficulty in treating esophageal cancer and coexistence of other organ cancer. For this reason the therapeutic guideline should be decided carefully. 